\title{
ANALISIS KINERJA KEUANGAN BANK MUAMALAT INDONESIA DIKAITKAN DENGAN PROGRAM AKSELERASI PERBANKAN SYARIAH
}

\author{
Roni Hamdani \\ Universitas Kuala Syiah Aceh \\ Email: Roni_hamdani@yahoo.com
}

\begin{abstract}
Abstrak:Tahun 2008 bagi perbankan syari'ah nasional mungkin berbeda dengan tahun-tahun sebelumnya. Kerja keras memenuhi target market share 5\% dari total aset perbankan nasional merupakan implementasi Visi Cetak Biru Pengembangan Perbankan Syari'ah Indonesia. Kekhawatiran target pangsa pasar $5 \%$ tidak tercapai memang menjadi pemikiran kalangan pemerintah, praktisi, pemerhati, peneliti maupun akademisi perbankan syari'ah.
\end{abstract}

Kata Kunci: bank Mu'amalat, akselerasi, bank syariah

\section{Pendahuluan}

Kebijakan dual-banking system pada tahun 1992 masih belum tercermin dalam realitas karena dalam kenyataan sampai saat ini pangsa pasar bank syariah belum signifikan. Sementara, survey preferensi (2000-2005) menunjukkan potensi pasar bank syariah (domestik) cukup besar ditambah dengan perkembangan yang pesat perbankan/lembaga keuangan internasional. Industri perbankan secara nasional masih menghadapi permasalahan mengoptimalkan fungsi intermediasinya. Selain itu Bank Indonesia memiliki komitmen mendukung pertumbuhan ekonomi nasional dimana sektor perbankan menjadi motor penggeraknya. ${ }^{1}$ 
Uraian di atas merupakan latar belakang dicanangkannnya program akselerasi pengembanganperbankan syariah oleh Bank Indonesia. Program tersebut tersebut bertujuan untuk mencapai market share perbankan syariah sebesar $5 \%$ pada akhir tahun 2008 dengan tetap meperhatikan prinsip kehati-hatian dan kepatuuhan terhadap prinsip syariah.

Tahun 2008 bagi perbankan syari'ah nasional mungkin berbeda dengan tahun-tahun sebelumnya. Kerja keras memenuhi target market share 5\% dari total aset perbankan nasional merupakan implementasi Visi Cetak Biru Pengembangan Perbankan Syari'ah Indonesia. Kekhawatiran target pangsa pasar 5\% tidak tercapai memang menjadi pemikiran kalangan pemerintah, praktisi, pemerhati, peneliti maupun akademisi perbankan syari'ah.

Pada akhir 2006, pada saat pencanangan Akselerasi Pengembangan Perbankan Syariah market share bank syariah baru mencapai 1,58 \%, yaitu sebesar 26,68 triliun. Dan data terakhir sampai dengan Juni 2008, diperoleh data dari Statistik Perbankan Syariah (SPS) Bank Indonesia bahwa market share bank syariah terhadap total aset perbankan nasional baru mencapai 2,08 $\%$, yaitu 41,08 triliun, masih jauh dari angka yang ditargetkan bahkan belum mencapai setengahnya. Untuk mempercepat hal tersebut BI menetapkan Kebijakan Akselerasi Perkembangan Perbankan Syari'ah 2007-2008.

\section{Pentingnya Perencanaan Kinerja Menurut Al Quran}

Pentingnya merencanakan kinerja keuangan secara implisit tercantum di dalam Al Quran, surat Al 'Ashr (103) : 1-3. Bahwasanya esok itu harus lebih baik dari sekarang, bahkan jika kualitas kinerja sekarang sama dengan sebelumnya, maka masih dikatakan merrugi.

"Demi masa. Sesungguhnya manusia itu benar-benar dalam kerugian. Kecuali orang-orang yang beriman dan mengerjakan amal saleh dan nasehat menasehati supaya mentaati kebenaran dan nasehat menasehati supaya menetapi kesabaran."

E. Siregar (Kepala Biro Penelitian, Pengembangan dan Pengaturan Perbankan Syariah Bank Indonesia) pada acara Ijtima' Ulama (Annual Meeting) DPS pada tanggal 14 Agustus 2007 di Cisarua-Bogor. 
Selain itu, Islam juga mengajarkan pentingnya merencanakan kinerja di masa yang akan datang terdapat dalam surat Al Hasyr (59) ayat 18.

"Hai orang-orang yang beriman, bertakwalah kepada Allah dan hendaklah setiap diri memperhatikan apa yang telah diperbuatnya untuk hari esok (akhirat); dan bertakwalah kepada Allah, sesungguhnya Allah Maha Mengetahui apa yang kamu kerjakan."

Secara implisit, ayat ini dapat diterapkan ke dalam berbagai sektor guna memicu peningkatan kualitas kinerja dalam semua segmen kehidupan termasuk di dalamnya sektor perbankan syariah yang mengiginkan adanya masa depan yang lebih baik dalam assetnya. Sehingga kainginan tersebut harus disusun dan direncanakan secara sistematis, kemudian dilaksanakan dengan baik. Dengan demikian, Direktorat Perbankan Syariah Bank Indonesia telah mengamalkan intisari yang diajarkan oleh Al Quran mengenai planing kinerja yang terukur.

\section{Program Akselerasi Pengembangan Perbankan Syariah}

Program Akselerasi Pengembangan Perbankan Syariah 2007-2008 adalah program yang dicanangkan oleh Bank Indonesia. Melalui Gubernur pada saat itu, Burhanuddin Abdullah, program ini dicanangkan pada hari Senin, 11 Desember 2006 di Jakarta.

Program ini bertujuan mencapai share perbankan syariah sebesar 5\% pada akhir tahun 2008 dengan tetap mempertahankan prinsip kehatihatian dan kepatuhan terhadap prinsip syariah. ${ }^{2}$

Menurut Burhanudin peningkatan peran perbankan syariah yang lebih besar memerlukan kesamaan visi dari semua stakeholders. Peran perbankan syariah yang semakin besar dalam perbankan nasional diyakini akan memberikan kontribusi positif bagi pertumbuhan ekonomi nasional. Hal tersebut dijelaskan dalam sambutannya pada saat pencanangan program akselerasi tersebut. ${ }^{3}$

${ }^{2}$ Bank Indonesia, "Kebijakan Akselerasi Pengembangan Perbankan Syariah 20072008”, (Jakarta : Bank Indonesia, 2006), h.3.

${ }^{3}$ Direktorat Perencanaan Strategis dan Biro Hubungan Masyarakat Bank Indonesia, "Program Akselerasi Pengembangan Perbankan Syariah Dimulai", diterbitkan pada tanggal 


\section{Latar Belakang Pencanangan Program Akselerasi Perbankan Syariah 4}

a. Kebijakan dual banking system pada tahun 1992 masih belum tercermin dalam realitas karena dalam kenyataan karena sampai saat ini pangsa pasar bank syariah belum signifikan (Oktober 2006 :1,5\%)

b. Survey preferensi (2000-2005) menunjukkan potensi pasar bank syariah (domestik) yang cukup besar ditambah dengan perkembangan yang pesat perbankan/keuangan syariah internasional

c. Industri perbankan secara nasional masih menghadapi permasalahan mengoptimalkan fungsi intermediasi. Selain itu Bank Indonesia memiliki komitmen mendukung pertumbuhan ekonomi nasional (PDB growth 6\%) dimana sektor perbankan nasional menjadi motor penggeraknya.

\section{Pilar Program Akselerasi Pengembangan Perbankan Syariah. ${ }^{5}$}
a. Penguatan Kelembagaan Bank Syariah
b. Pengembangan Produk Bank Syariah
c. Intensifikasi Edukasi Publik \& Aliansi Mitra Strategis
d. Peningkatan Peranan Pemerintah \& Penguatan Kerangka Hukum Bank Syariah
e. Penguatan SDM Bank Syariah
f. Penguatan Pengawasan Bank Syariah

\section{Profil BMI}

PT Bank Syariah Muamalat Indonesia Tbk adalah bank umum pertama di Indonesia yang menerapkan prinsip Syariah Islam dalam menjalankan operasionalnya. Didirikan di Republik Indonesia pada tanggal 1 Nopember 1991 atau 24 Rabius Tsani 1412 H berdasarkan akta Notaris Yudo Paripurno, S.H., No. 1. Akta pendirian ini telah disahkan oleh Menteri Kehakiman Republik Indonesia dalam Surat Keputusan No.C2-2413.HT.01.01.Th.92 tanggal 21 Maret 1992 dan diumumkan dalam Berita Negara No. 34 tanggal

11 Desember 2006, artikel diakses pada 19 September 2008, dari http://www.bi.go.id.

${ }^{4}$ Bank Indonesia, "Kebijakan Akselerasi Pengembangan Perbankan Syariah 20072008", Jakarta : Bank Indonesia, 2006, h.2.

${ }^{5}$ Ibid., h.7 
28 April 1992, Tambahan No. 1919A. Bank Muamalat mulai beroperasi tanggal 27 Syawwal $1412 \mathrm{H}$ atau 1 Mei $1992 .{ }^{6}$

Anggaran dasar Bank telah mengalami beberapa kali perubahan, terakhir dengan perubahan yang didokumentasikan dalam akta Notaris Yudo Paripurno, S.H., No. 237 tanggal 28 April 2005, yang kemudian direvisi dengan akta notaris No.150 tanggal 27 September 2005 khususnya mengenai perubahan modal dasar Bank. Perubahan tersebut telah disahkan oleh Menteri Kehakiman dan Hak Asasi Manusia Republik Indonesia dengan Surat Keputusan No. C-32981.HT.01.04.TH.2005 tanggal 13 Desember 2005, serta telah diumumkan dalam Berita Negara Republik Indonesia nomor 13 Tambahan No.1633, tanggal 14 Pebruari 2006. ${ }^{7}$

Ide mendirikan Bank Muamalat Indonesia (BMI) tercetus dalam sebuah lokakarya MUI bertema "Masalah Bunga Bank dan Perbankan" yang diadakan pada pertengahan Agustus 1990 di Cisarua, Bogor. Peserta lokakarya sepakat menugaskan Komite Pengembangan Ekonomi umat membentuk sebuah bank yang kegiatannya berpedoman pada Syariah Islam. keputusan ini dikukuhkan dalam Munas MUI akhir Agustus 1990 di Jakarta. Tim yang terbentuk, yang kemudian dikenal sebagai Tim Perbankan MUI, diketuai Dr. H.M. Amin Aziz.

Pada tanggal 27 Oktober 1994, hanya dua tahun setelah didirikan, Bank Muamalat berhasil menyandang predikat sebagai Bank Devisa. Pengakuan ini semakin memperkokoh posisi Perseroan sebagai bank syariah pertama dan terkemuka di Indonesia dengan beragam jasa maupun produk yang terus dikembangkan.

\section{Sumber Permodalan BMI}

Sumber permodalan Bank Muamalat berasal lebih dari 800.000 masyarakat muslim Indonesia dan muslim internasional melalui Islamic Development Bank (IDB) Jeddah, Arab Saudi. Pada RUPS tanggal 21 Juni 1999 IDB secara resmi menjadi salah satu pemegang saham Bank Muamalat. Modal dan pengelolaan Bank Muamalat sampai saat ini tetap murni Produk dan

6 "Catatan Atas Laporan Keuangan PT Bank Muamalat Indonessia Tbk Periode Juni 2008”, h.1, artikel ini diakses pada 9 Oktober 2008 dari http://www.muamalatbank.com

${ }^{7}$ Ibid., h. 1 
layanan perbankan Muamalat didasarkan pada prinsip dan kaidah syariah sesuai komitmen: "Berasal Sumber yang Bersih, Berbagi Hasil yang Murni". Produk penghimpunan serta penanaman dana dilandaskan pada kaidah murni syariah dan pemberdayaan modal secara produktif. ${ }^{8}$

\section{Visi dan Misi BMI $^{9}$}

\section{Visi}

Menjadi bank syariah utama di Indonesia, dominan di pasar spiritual, dikagumi di pasar rasional.

\section{Misi}

Menjadi ROLE MODEL Lembaga Keuangan Syariah dunia dengan penekanan pada semangat kewirausahaan, keunggulan manajemen dan orientasi investasi yang inovatif untuk memaksimumkan nilai bagi stakeholder.

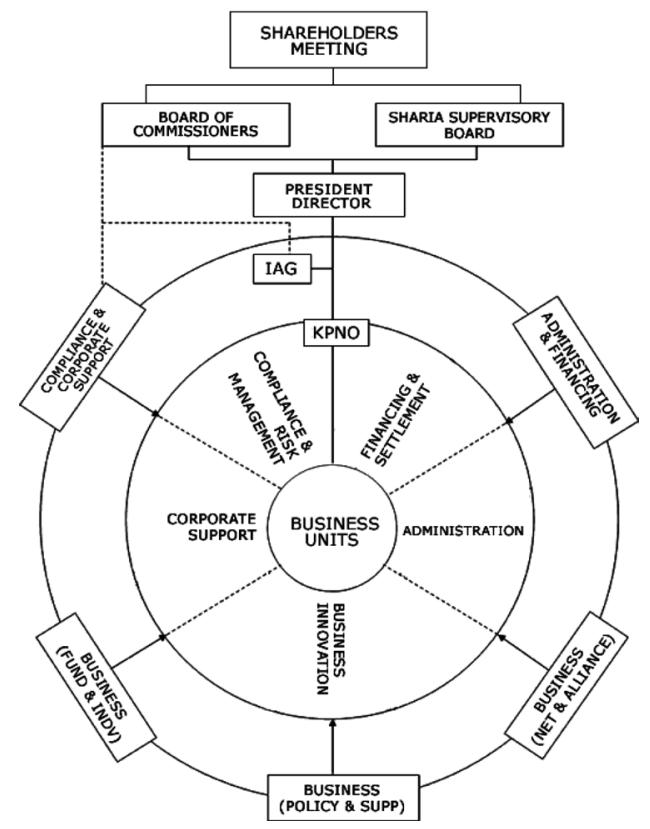

${ }^{8}$ PT Bank Muamalat Indonesia Tbk, "Laporan Tahunan 2007" artikel ini diakses pada 24 September 2008 dari http://www. muamalatbank.com

${ }^{9}$ PT Bank Muamalat Indonesia Tbk, "Visi dan Misi", artikel diakses pada 18 September 2008 dari http://www. muamalatbank.com 


\section{Struktur Organisasi Bank Muamalat}

Gambar 3.1. Struktur Organisasi Bank Muamalat

Struktur Organisasi dan Bagian-bagiannya

\begin{tabular}{|c|c|}
\hline $\begin{array}{l}\text { INTERNAL AUDIT } \\
\text { GROUP }\end{array}$ & $\begin{array}{l}\text { - Resident Auditor } \\
\text { - Administration and Information Technology } \\
\text { System } \\
\text { - Data Control } \\
\text { - Financing and Treasury } \\
\text { - Monitoring and Audit Analysis }\end{array}$ \\
\hline CORPORATE SUPPORT & $\begin{array}{l}\text { - Corporate Secretary } \\
\text { - Communication and Public Relation } \\
\text { - Corporate Legal and Investor Relation } \\
\text { - Protocolair and Internal Relation } \\
\text { - Corporate Planning }\end{array}$ \\
\hline ADMINISTRATION & $\begin{array}{l}\text { - MIS and Tax } \\
\text { - Personnel Administration and Logistic } \\
\text { - Information and Technology } \\
\text { - Technical Support and Data Center } \\
\text { - Operation Supervision and SOP }\end{array}$ \\
\hline $\begin{array}{l}\text { FINANCING \& } \\
\text { SETTLEMENT }\end{array}$ & $\begin{array}{l}\text { - Financing Supervision \& SOP } \\
\text { - F.I and Sharia Financial Institution } \\
\text { - Financing Product Development }\end{array}$ \\
\hline BUSINESS UNITS & $\begin{array}{l}\text { - Operational Head Office } \\
\text { - Coordinating Branches and Branches } \\
\text { Office } \\
\text { - DPLK }\end{array}$ \\
\hline BUSINESS INNOVATION & $\begin{array}{l}\text { - System Development and SOP } \\
\text { - Product Development and } \\
\text { Maintenance } \\
\text { - Treasury } \\
\text { - Network Alliance (POS, Da'i } \\
\text { Muamalat, Pegadaian) } \\
\text { - Shar-E and Gerai Optimizing } \\
\text { - Virtual Banking Operations (Call } \\
\text { Center and Card Center) }\end{array}$ \\
\hline
\end{tabular}




\section{Analisis Camels Terhadap Kinerja Bmi}

Dalam menganalisa sejauh mana kinerja keuangan BMI digunakan "kacamata" CAMELS yang fokus kepada CAR, FDR, NPF, ROA, ROE, ATMR dan Modal.

\section{$C A R$}

Capital Adequacy Rasio (CAR) adalah rasio kecukupan modal yang diwajibkan oleh Bank Indonesia, atau bisa disebut juga sebagai Kewajban Penyediaan Modal Minimum (KPMM), dimana setiap bank minimal harus mempunyai rasio CAR sebesar $8 \%$ dalam operaionalnya.

Berikut ini rasio CAR BMI pada kwartal I 2007 sampai kwartal III 2008.

\begin{tabular}{|l|l|l|l|l|l|l|l|}
\hline Periode & $\begin{array}{l}\text { K I } \\
\text { Mar '07 }\end{array}$ & $\begin{array}{l}\text { K II } \\
\text { Jun '07 }\end{array}$ & $\begin{array}{l}\text { K III } \\
\text { Sep ‘07 }\end{array}$ & $\begin{array}{l}\text { K IV } \\
\text { Des ‘07 }\end{array}$ & $\begin{array}{l}\text { K I } \\
\text { Mar '08 }\end{array}$ & $\begin{array}{l}\text { K II } \\
\text { Jun ‘07 }\end{array}$ & $\begin{array}{l}\text { K III } \\
\text { Sep ‘07 }\end{array}$ \\
\hline CAR & $14,85 \%$ & $12,66 \%$ & $11,23 \%$ & $10,69 \%$ & $11,46 \%$ & $9,57 \%$ & 11,25 \\
\hline
\end{tabular}

Tabel 4.1. Rasio CAR kwartal I 2007 sampai kwartal III 2008 Sumber : Bank Muamalat Indonesia

Dan ilustrasi CAR dapat dilihat dari grafik di bawah ini.

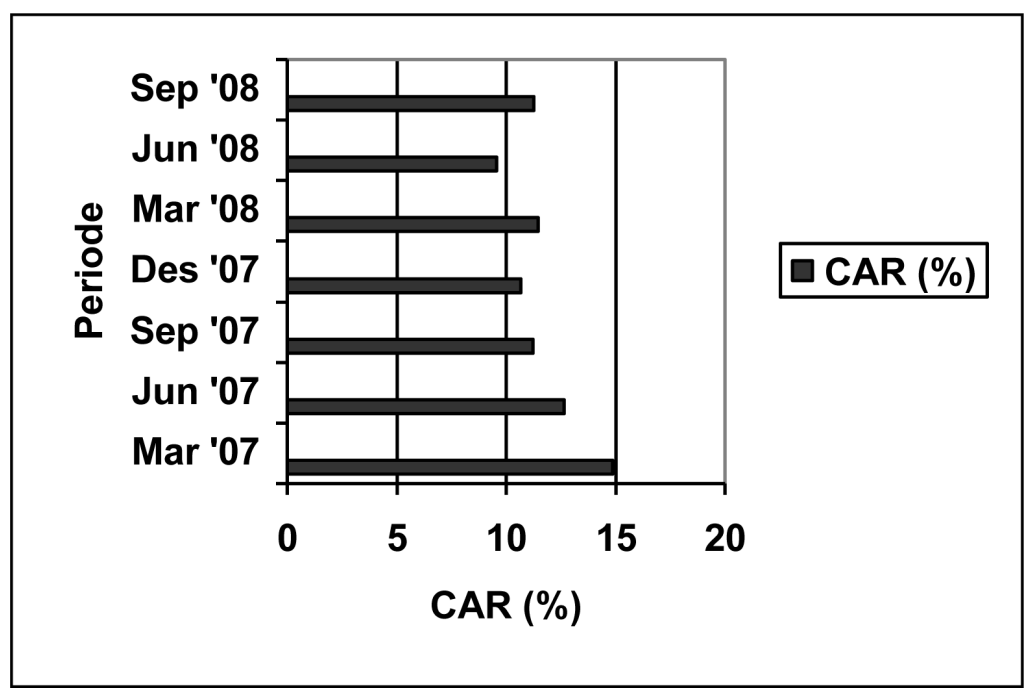

Gambar 4.1. Grafik rasio CAR BMI 
Pada dasarnya semakin besar rasio CAR, menunjukkan semakin bagus kinerja keuangannya dan memberikan sinyal bahwa bank tersebut sehat. Dari data di atas diketahui bahwa pada kwartal I (Maret 2007) merupakan nilai CAR yang terbesar sebesar 14,85\% dibandingkan dengan kwartal berikutnya. Ini menunjukkan bahwa pada periode tersebut BMI ada pada tingkat kesehatan yang tinggi. Dimana lebih besar 6,85\% dibandingkan yang diwajibkan oleh Bank Sentral. Namun sebenarnya semua rasio di atas menunjukkan bahwa BMI sehat, sebab rata-rata CAR nya di atas 8\%. Dan jika CAR ditekan hingga 8\% sekalipun BMI masih tetap beroperasi dengan baik. Akan tetapi jika rasio CAR berada di bawah $8 \%$, maka bank tersebut berasda di ambang masalah permodalan, dan akan mengalami negative spreed.

\section{ATMR}

Aktiva Tertimbang Menurut Risiko adalah faktor pembagi (denominator) dari CAR. Dan ATMR menjadi dasar dalam perhitungan berapa modal yang dibutuhkan oleh bank dalam menjalankan fungsi intermediarynya. Yang dimaksud aktiva dalam perhitungan ini mencakup baik aktiva yang tercantum dalam neraca, maupun aktiva yang yang bersifat administratif sebagaimana tercermin dalam kewajiban yang masih bersifgat kontigen dan atau komitmen yang disediakan bagi pihak ketiga. Terhadap masingmasing jenis aktiva tersebut ditetapkan bobot risiko yang besarnya didasarkan pada kadar risiko yang terkandung dalam aktiva itu sendiri. Dengan demikian semakin besar nominal ATMR, menunjukkan semakin bagus kinerja bank, namun hal ini tetap akan sejalan dengan besarnya CAR dan modal bank.

Berikut ini rasio ATMR BMI periode 2007-2008.

\begin{tabular}{|c|c|c|c|c|c|c|c|}
\hline Periode & $\begin{array}{c}\text { K I } \\
\text { Mar '07 }\end{array}$ & $\begin{array}{c}\text { K II } \\
\text { Jun '07 }\end{array}$ & $\begin{array}{c}\text { K III } \\
\text { Sep '07 }\end{array}$ & $\begin{array}{c}\text { K IV } \\
\text { Des ‘07 }\end{array}$ & $\begin{array}{c}\text { K I } \\
\text { Mar '08 }\end{array}$ & $\begin{array}{c}\text { K II } \\
\text { Jun ‘07 }\end{array}$ & $\begin{array}{c}\text { K III } \\
\text { Sep ‘07 }\end{array}$ \\
\hline ATMR & 6.499 & 7.248 & 8.291 & 7.914 & 9.085 & 9.879 & 10.754 \\
\hline
\end{tabular}


Tabel 4.2. ATMR BMI 2007-2008 (miliar rupiah) Sumber Bank Muamalat

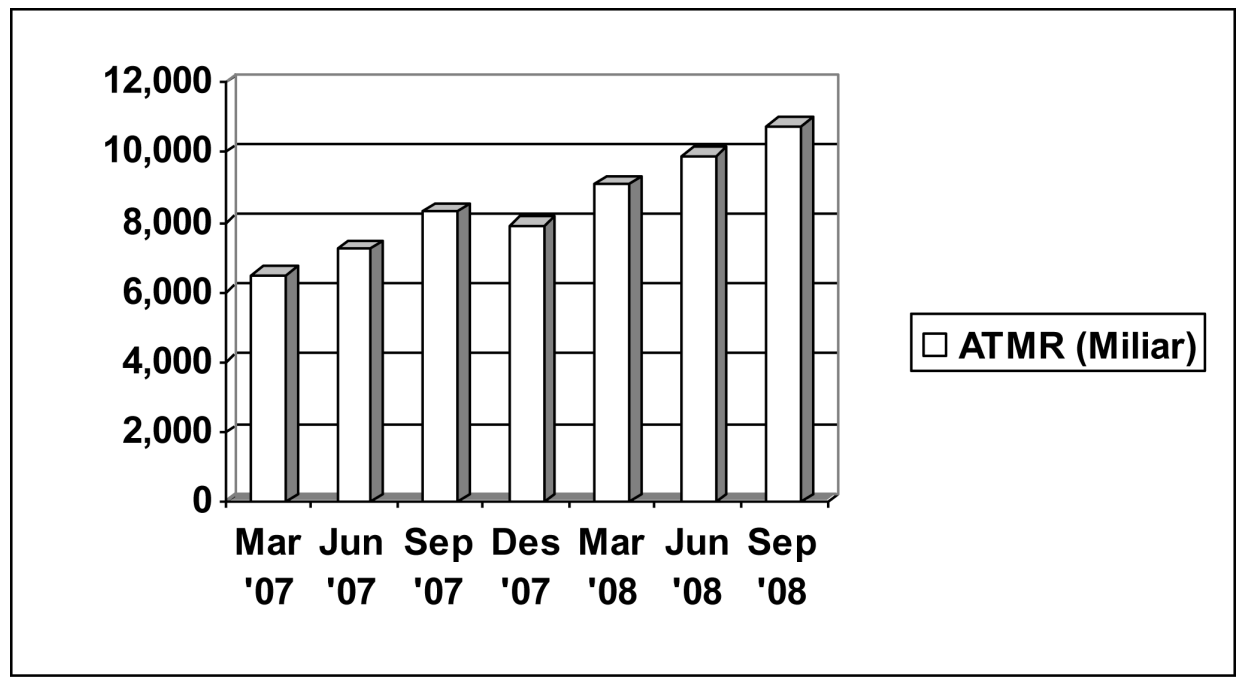

Gambar 4.2. Grafik ATMR kwartalan 2007-2008 (Miliar Rupiah)

Dari data di atas kita dapat mengetahui bahwa setiap kwartal mengalami kenaikan yang besarnya berbeda. Kecuali untuk kwartal IV pada Desember 2007, mengalami penurunan sebesar 377 miliar dari 8.291 miliar menjadi 7.914 miliar. Hal ini pun akan berpengaruh kepada nilai CAR dan modal bank. Dimana pada kwartal IV 2007 tersebut CAR juga mengalami penurunan sebesar $0,54 \%$ dari $11,23 \%$ pada kwartal III menjadi 10,69\% pada kwartal IV tahun 2007. Perbedaan dan fluktuasi ATMR disebabkan oleh berubahnya komposisi aktiva setiap saat karena pos-pos pada aktiva berubah. ATMR diperoleh dengan cara mengalikan aktiva-aktiva dengan bobot resikonya masing-masing yang satu sama lain berbeda, sesuai dengan peraturan yang ditetapkan oleh BI dalam PBI No. 8/18/PBI/2006 dan PBI No. 8/6/PBI/2006.

\section{Modal}

Yang dimaksud modal disini adalah yang digunakan oleh bank untuk beroperasi terutama produk financing dan untuk mengcover risikonya, yaitu berupa risiko kredit dan risiko pasar. 
Berikut ini rasio modal BMI pada kwartal I 2007 sampai kwartal III 2008 (dalam miliar rupiah).

\begin{tabular}{|c|c|c|c|c|c|c|c|}
\hline Periode & $\begin{array}{c}\text { K I } \\
\text { Mar } \\
\text { '07 }\end{array}$ & $\begin{array}{c}\text { K II } \\
\text { Jun } \\
\text { '07 }\end{array}$ & $\begin{array}{c}\text { K III } \\
\text { Sep } \\
\text { '07 }\end{array}$ & $\begin{array}{c}\text { K IV } \\
\text { Des } \\
\text { '07 }\end{array}$ & $\begin{array}{c}\text { K I } \\
\text { Mar '08 }\end{array}$ & $\begin{array}{c}\text { K II } \\
\text { Jun '07 }\end{array}$ & $\begin{array}{c}\text { K III } \\
\text { Sep } \\
\text { '07 }\end{array}$ \\
\hline Modal & 965 & 917 & 931 & 846 & 1.041 & 945 & 1.210 \\
\hline
\end{tabular}

Tabel 4.3. Modal BMI periode 2007-2008 dalam kwartalan Sumber : Bank Muamalat Indonesia

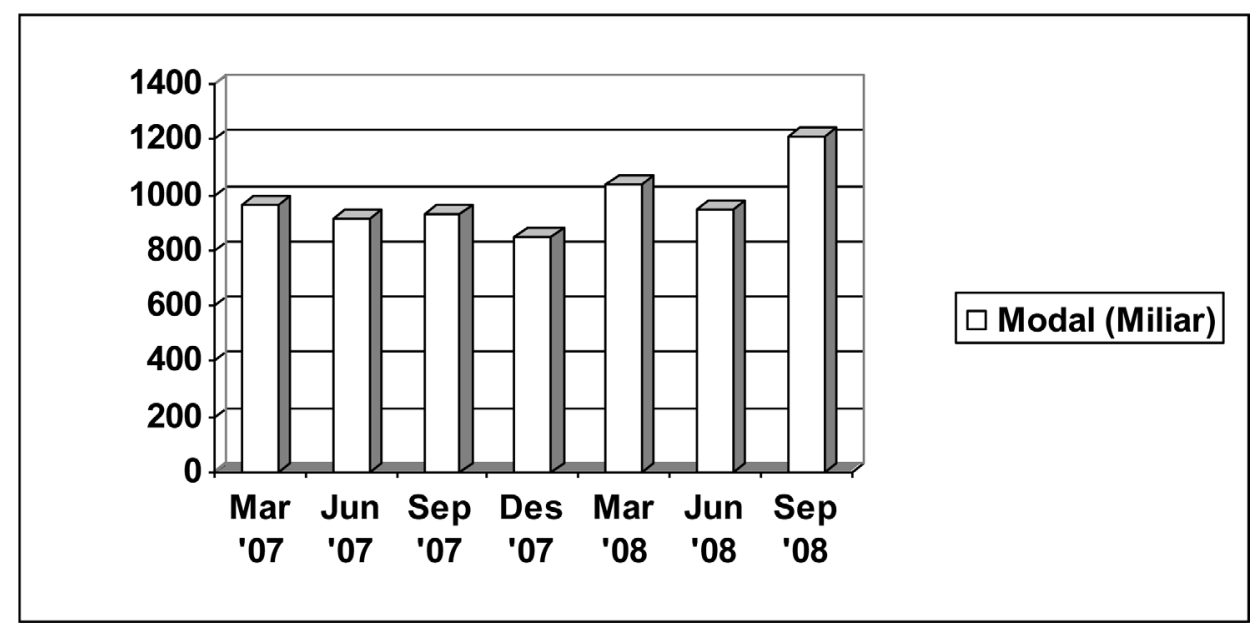

Gambar 4.3. Grafik modal BMI periode 2007-2008 (Miliar Rupiah)

Gambar di atas menunjukkan bahwa modal BMI mengalami fluktuasi sesuai dengan kebutuhan dan target pembiayaan yang direncanakan. Selain itu, ada faktor non teknis yang berpengaruh, yaitu keadaan ekonomi dan merosotnya nilai tukar rupiah pada akhir 2007. sehingga mengakibatkan modal menurun ke level 846 miliar. Meskipun ini tidak berarti BMI dalam keadaan kurang sehat namun hal ini hanya menjadi indikator menurunnya target pembiayaan yang diberikan kepada pihak ketiga yang mungkin telah direncanakan. Karena biasanya pada akhir tahun bank dituntut untuk menjaga likuiditasnya agar pelaporan dalam annual report sesuai dengan yang diharapkan. 


\section{Penutup}

Pada dasarnya semakin besar rasio CAR, menunjukkan semakin bagus kinerja keuangannya dan memberikan sinyal bahwa bank tersebut sehat. Pada kwartal I (Maret 2007) nilai CAR yang tertinggi pada periode 2007 sebesar 14,85\% dibandingkan dengan kwartal berikutnya. Ini menunjukkan bahwa pada periode tersebut BMI ada pada tingkat kesehatan yang tinggi. Dimana lebih besar 6,85\% dibandingkan yang diwajibkan oleh Bank Sentral. Namun sebenarnya semua rasio di atas menunjukkan bahwa BMI sehat, sebab rata-rata CAR nya di atas 8\%. Dan jika CAR ditekan hingga 8\% sekalipun BMI masih tetap beroperasi dengan baik. Akan tetapi jika rasio CAR berada di bawah $8 \%$, maka bank tersebut berasda di ambang masalah permodalan, dan akan mengalami negative spreed.

Pada kwartal IV 2007, mengalami penurunan sebesar 377 miliar dari 8.291 miliar menjadi 7.914 miliar. Hal ini pun akan berpengaruh kepada nilai CAR dan modal bank. Dimana pada kwartal IV 2007 tersebut CAR juga mengalami penurunan sebesar $0,54 \%$ dari $11,23 \%$ pada kwartal III menjadi $10,69 \%$ pada kwartal IV tahun 2007. Perbedaan dan fluktuasi ATMR disebabkan oleh berubahnya komposisi aktiva setiap saat karena pos-pos pada aktiva berubah. ATMR diperoleh dengan cara mengalikan aktiva-aktiva dengan bobot resikonya masing-masing yang satu sama lain berbeda, sesuai dengan peraturan yang ditetapkan oleh BI dalam PBI No. 8/18/PBI/2006 dan PBI No. 8/6/PBI/2006.

Dari annual report diperoleh data bahwa aset Bank Muamalat pada Desember 2007 sebesar 10,57 triliun. Sedangkan Market Share Bank Syariah saat itu masih sekitar 1,76 \% yaitu sebesar 33,28 triliun. Sehingga kontribusi aset Bank Muamalat terhadap total aset Bank Syariah sebesar 31,76 \%.

Pada periode yang sama FDR Bank Muamalat mencapai 99,16 \% naik dari periode Desember 2006 sebesar 2,22 \% menjadi 96,94 \%. Sedangkan NPF-nya 1,33\% turun dari tahun sebelumnya sebesar 3,51 \% yang mencapai 4,84 \%. Ini menunjukkan dalam setauhn kinerja Bank Muamalat sangat bagus, dan ini terbukti pula dari catatan bahwa Bank Muamalat merupakan penyumbang terbesar naiknya market share perbankan syariah.

Sedangkan data terakhir yang diperoleh dari neraca Bank Muamalat 
bahwa aset BMI pada posisi September 2008 mencapai 12,10 Triliun. Dengan rasio ROA 2,62\%, ROE 33,21\%, FDR 106,39\%, dengan NPF sebesar $3,88 \%$, dan CAR sebesar 11,34\%.

Pada September 2008 aset BMI sebesar 12,10 triliun. dan pada posisi yang sama total aset perbankan syariah mencapai 45,86 triiun. Ini berarti Bank Muamalat menyumbangkan 26,38\%. Sedangkan 73,62\% disumbang oleh dua Bank Umum lainnya disertai Unit Usaha Syariah dan BPRS lainnya-23 Unit Usaha Syariah (UUS) serta 107 Bank Perkreditan Rakyat Syariah (BPRS)—secara kolektif. Namun secara individu, kontribusi Bank Muamlat lebih besar dibandingkan Bank Umum lainnya.

\section{Pustaka Acuan}

Al Quran dan Hadits

Bank Indonesia, Kebijakan Akselerasi Pengembangan Perbankan Syariah 2007-2008, Jakarta : Bank Indonesia, 2006

—, Upaya Pencapaian Akselerasi Perbankan Syariah Ditinjau dari Kinerja Keuangan, Jakarta : PCPM Bank Indonesia XXVII Tahap 2, 2007

—

—, Statistik Perbankan Syariah, Jakarta : Bank Indonesia, 2008

—, Statistik Perbankan Indonesia, Jakarta : Bank Indonesia, 2008

—

— Cetak Biru Perbankan Syariah Indonesia, Jakarta: Bank Indonesia, 2002

— , Pedoman Akuntansi Perbankan Syariah Indonesia (PAPSI), Jakarta: Bank Indoensia, 2003

— Penilaian Tingkat Kesehatan Bank Umum, Jakarta : Bank Indonesia, 2004

_ SuratEdaran kepada Semua Bank Umumyang Melaksanakan Kegiatan Usaha Secara Konvensional di Indonesia Perihal Sistem Penilaian Tingkat Kesehatan Bank Umum, Jakarta : Bank Indonesia, 2004

Dewan Syariah Nasional, Himpunan Fatwa Deewan Syariah Nasional, Jakarrta : Dewan Syariah Nasional dan Bank Indonesia, Edisi Ketiga, 
2006

http://www.bi.go.id

http://www.muamalatbank.com

http://www.Islamicaccounting.blogspot.com

http://www.republika.co.id

http://www.pkes.org

http://mrzie3r.wordpress.com

Husnan, Suad, Dr.,M.B.A., Manajemen Keuangan Teori dan Penerapan

(Keputusan Jangka Panjang), Yogyakarta : BPFE-Yogyakarta, 2000, Edisi 4

Jusuf, Jopie, Analisis Kredit untuk Account Officer, Jakarta : PT Gramedia Pustaka Utama, 2006

Karim, Adiwarman, Bank Islam; Analiis Fiqh dan Keuangan, Jakarta : PT RajaGrafindo Persada, 2004

Kasmir, SE.,MM., Dasar-Dasar Perbankan, Jakarta: PT RajaGrafindo Persada, 2004

Muhammad, Manajemen Pembiayaan Bank Syariah, Yogyakarta : Akademi Manajemen Perusahaan YKPN, 2005

— Manajemen Bank Syariah, Yogyakarta : (UPP) AMPYKPN, 2005

A. Mulawarman, Aji Said Dedi, Kritik Market Share 5\% Bank Syariah, Yogyakarta :www.mulawarman.blogspot.com, 2007

Muljono, Teguh Pudjo, Drs.,Akuntan, Analisa Laporan Keuangan Untuk Perbankan, Jakartta : Djambatan, 1990

Sakti, Ali, M.Ec., Analisis Teoritis Ekonomi Islam ; jawaban atas kekacauan Ekonomi Modern, Jakarta : Paradigma \& Aqsa Publishing, 2007

Suprayitno, Eko, Ekonomi Islam Pendekatan Ekonomi Makro Islam dan Konvensional, Yogyakarta : Graha Ilmu, 2005

Suyatno, Thomas, Dr., dkk., Kelembagaan Perbankan, Jakarta, PT Gramedia Pustaka Utama dan STIE Perbanas, Edisi Ketiga

Taswan, SE.,M.Si., Akuntansi Perbankan Transaksi Dalam Valuta Rupiah, Semarang : UPP AMP YKP, 2003 